NBER WORKING PAPER SERIES

\title{
THE CHANGING ROLE OF AUDITORS IN CORPORATE TAX PLANNING
}

\author{
Edward L. Maydew \\ Douglas A. Shackelford \\ Working Paper 11504 \\ http://www.nber.org/papers/w11504
}

\author{
NATIONAL BUREAU OF ECONOMIC RESEARCH \\ 1050 Massachusetts Avenue \\ Cambridge, MA 02138 \\ June 2005
}

We acknowledge the thoughtful comments of conference participants, Robert Bushman, Courtney Edwards, Steve Kaplan, Lil Mills, Jana Raedy, Kevin Raedy, John Robinson, Richard Sansing, Joel Slemrod, and numerous practitioners at leading accounting firms and corporations. We appreciate the research assistance of Scott Dyreng, Allison Evans, and Vincent Thorn. A prior version of this paper was titled "Corporate Tax Planning in a Sarbanes-Oxley World." The views expressed herein are those of the author(s) and do not necessarily reflect the views of the National Bureau of Economic Research.

(C2005 by Edward L. Maydew and Douglas A. Shackelford. All rights reserved. Short sections of text, not to exceed two paragraphs, may be quoted without explicit permission provided that full credit, including () notice, is given to the source. 
The Changing Role of Auditors in Corporate Tax Planning

Edward L. Maydew and Douglas A. Shackelford

NBER Working Paper No. 11504

July 2005

JEL No. H2, M4, L1, L5

\section{$\underline{\text { ABSTRACT }}$}

This paper examines changes in the role that auditors play in corporate tax planning following recent events, including the well-known accounting scandals, passage of the Sarbanes-Oxley Act, and regulatory actions by the SEC and $\mathrm{PCAOB}$. On the whole, these events have increased the sensitivity to and scrutiny of auditor independence. We examine the effects of these events on the market for tax planning, in particular the longstanding link between audit and tax services. While the effects are recent, they are already being seen in the data. Specifically, there has already been a dramatic shift in the market for tax planning away from obtaining tax planning services from one's auditor. We estimate that the ratio of tax fees to audit fees paid to the auditors of firms in the S\&P 500 decline from approximately one in 2001 to one-fourth in 2004. At the same time, we find no

evidence of a general decline in spending for tax services. In sum, the evidence indicates a decoupling of the longstanding link between audit and tax services, such that firms are shifting their purchase of tax services away from their auditor and towards other providers.

Edward L. Maydew

Kenan-Flagler Business School

University of North Carolina

Campus Box 3490

McColl Building

Chapel Hill, NC 27599-3490

edward_maydew@unc.edu
Douglas A. Shackelford

Kenan-Flagler Business School

University of North Carolina

Campus Box 3490

McColl Building

Chapel Hill, NC 27599-3490

and NBER

doug_shack@unc.edu 


\section{The Changing Role of Auditors in Corporate Tax Planning}

\section{Introduction}

This paper examines the changing role that auditors play in corporate tax planning in the face of the recent events, including the well-known accounting scandals, passage of the Sarbanes-Oxley Act, and regulatory actions by the Securities and Exchange Commission (SEC) and the Public Company Accounting Oversight Board (PCAOB). Although the events are recent, still being debated, and the data limited, one thing is clear in the preliminary data. The amount of tax services that audit firms provide to their audit clients has declined dramatically during the period 2001-2004. Furthermore, most of the tax work appears to have shifted among accounting firms because the amount of tax work that accounting firms perform for non-audit clients has increased sharply.

We find that in 2001, S\&P 500 companies, on average, paid their auditors about the same fees for their audit work as they did for their tax work (i.e., the combination of tax compliance, tax advice and tax consulting). Two years later in 2003, the S\&P 500 were paying twice as much for audit work as tax work. By 2004, we estimate that the average S\&P 500 firm was paying their auditor four times more for audit work than tax work. This striking shift has occurred because audit clients are both paying more for audit work and spending less for tax services from their auditor. The total tax practice of the largest accounting firms (from both audit and nonaudit clients) has held steady during this period, indicating that that what we are observing is a shift in clients among the providers of tax service rather than a general decline in tax services.

Several related events likely contributed to the decline in auditor-related tax services and the increase in non-auditor provided tax services. A rash of accounting scandals in 2001 and 2002 led to increased scrutiny of auditors and auditor independence. Congress responded by 
enacting Sarbanes-Oxley in the summer of 2002. ${ }^{1}$ A primary purpose of Sarbanes-Oxley is to ensure (some would argue restore) the independence of the auditor. To ensure that auditors are independent in fact and in appearance, and therefore are not facing conflicting incentives when issuing an audit opinion, the sweeping legislation, among other things, restricts the tax services that accountants can provide to their audit clients. ${ }^{2}$ Specifically, Sarbanes-Oxley requires that before an auditor is retained to perform tax services, the client must seek and obtain specific approval from the audit committee of the board of directors. No pre-approval is required when clients obtain tax services from a firm that is not their auditor. Follow-on regulations from the SEC place further restrictions on auditors by prohibiting them from providing certain types of tax planning services to their audit clients. ${ }^{3}$ Because accounting firms historically provided their audit clients with substantial tax planning, these restrictions are altering the process by which corporations manage their tax liabilities.

Regulation, however, does not fully account for the decline in auditor-provided tax services. Some companies have gone beyond the Sarbanes-Oxley restrictions. They no longer accept any non-audit services from their audit firm, including tax work. One reason for these self-imposed restrictions is to signal a high-quality audit, i.e., the auditor is not compromised by fees it receives from non-audit services. Companies completely dropping non-audit services are attempting to disassociate themselves from the negative publicity of accounting scandals

\footnotetext{
${ }^{1}$ The nine months preceding the passage of Sarbanes-Oxley were marked with several major criminal investigations involving corporate managers. Among these was Enron's earnings restatement on November 8, 2001; Adelphia's report of unbooked family loans on March 27, 2002; the tax evasion indictment of Tyco's CEO on June 4, 2002; the arrest of ImClone's CEO for insider trading on June 12, 2002; and WorldCom's admission of earnings overstatements on June 25, 2002.

${ }^{2}$ Note that the restrictions are placed on the accounting firm, not on an individual auditor. That is, a tax consultant working at an accounting firm is restricted in the services that he can provide an audit client, even if he had no role in the audit. Likewise, tax consulting opportunities are limited, even if no one associated with the audit played any role in the tax plan.

${ }^{3}$ SEC Release No. 33-8183, Strengthening the Commission's Requirements Regarding Auditor Independence (2003).
} 
involving perceived auditor compromise. One such case is Enron, where Arthur Andersen reportedly received over \$52 million in 2000, mostly from non-audit services (McLean and Elkind, 2003, p.145). Shareholder pressure also may be contributing to the decline in non-audit services. For example, the California Public Employees' Retirement System has a policy of opposing the election of audit committee members who approve non-audit services. ${ }^{4}$ In addition, they generally vote against retaining auditors that provide non-audit services. ${ }^{5}$ In sum, the combination of regulatory and self-imposed restrictions is decoupling the longstanding link between audit and tax services.

Why did firms obtain most of their tax services from their audit firm prior to the accounting scandals, the Sarbanes-Oxley Act, and regulatory changes by the SEC and PCAOB? The answer is that because all publicly-traded firms are required to have an audit and all privately-held businesses of any consequence acquire one, the firm conducting the audit historically enjoyed at least two significant advantages compared to other accounting firms. First, auditors learn a great deal about the client's business during the course of the audit and operate on the “inside," having access to the client’s internal financial information. Consequently, the auditor is often able to identify consulting opportunities, including tax consulting, more readily than other service providers. Second, the auditor typically has a working relationship with both the tax director and the CFO, who historically were the key people involved in the selection of tax providers. Often the CFOs and tax directors began their careers with the accounting firm that does the audit. They therefore understand the firm's audit and tax approach, and have longstanding, close relationships with the firm's personnel.

\footnotetext{
${ }^{4}$ See http://www.calpers-governance.org/viewpoint/speeches/anson041403.asp.

${ }^{5}$ See http://www.boardmember.com/network/index.pl?section=1024\&article_id=11985\&show=article.
} 
Compared to non-accounting providers of tax services, specifically law firms, accounting firms also enjoy some advantages. Because of long-standing financial accounting rules that are beyond the scope of this paper, whole classes of tax strategies (in general, those that defer taxable income or accelerate tax deductions) do not actually reduce the tax expense that shows up in the firm's financial statements. ${ }^{6}$ Paradoxically, this development means that only certain kinds of tax planning are actually useful at increasing the earnings that are reported to shareholders. With experts in both financial reporting and tax planning, accounting firms have a competitive advantage over law firms in designing corporate tax plans that reduce the actual taxes paid in a manner that also translates into reduced tax expense (and increased earnings) in the financial statements. Since earnings and earnings per share are viewed by CFOs as the most important determinants of share price (Graham et al., 2005), the ability to reduce taxes for financial accounting purposes is often critical to selling tax planning ideas.

In addition, the financial reporting perspective of accountants has shaped corporate tax planning. Accountants were central in positioning tax departments as corporate profit centers, where reducing effective tax rates was seen as a means of enhancing accounting earnings. This synergy meshes nicely with the managerial goal of enhancing shareholder value since earnings are a key component in valuation.

Accounting firms have also enjoyed advantages in providing tax services that require number crunching, something law firms typically do not do, and tax services that require coordination across offices in different countries, as the largest accounting firms have global footprints that dwarf those of even the largest law firms. On the other hand, law firms have had

\footnotetext{
${ }^{6}$ For details, see Appendix 2.2 of Scholes, et al. 2005. These rules are contained in Statement of Financial Accounting Standards (SFAS) 109, which was promulgated by the Financial Accounting Standards Board (FASB). The FASB is the private rule-making body primarily responsible for promulgating Generally Accepted Accounting Principles (GAAP).
} 
an advantage in providing high-end legal analysis such as writing opinion letters and, naturally, in tax litigation. Law firms also have the advantage of attorney client privilege, although it has been curtailed to some extent in recent court cases involving tax shelters.

Over time, accounting firms became key providers of corporate tax expertise to their audit clients, and accountants became the leading designers of many corporate tax plans. One recent example is the role accountants played in the proliferation of corporate tax shelters around the turn of the millennium. Many of the alleged shelters were developed by the largest accounting firms (Bankman, 2004). It is not obvious how corporate tax planning would have evolved without the central role of accountants. Similarly, it is not apparent how it will evolve with the pressure to decouple audit and tax so profoundly altering the process and systems by which corporations approach taxes. While the future is hazy, we will nevertheless hazard three predictions, which should be testable with more research and more data.

First, there will be disruptions to the tax function that should, to some extent, increase the cost of tax planning and increase corporate taxes paid. The development and implementation of a tax plan for a large corporation is a complex undertaking. It requires extensive knowledge of the company, its history and how the organization operates. It requires the coordination of parties with diverse interests and information, involving domestic and foreign operations across multiple segments of the business, including production, marketing, finance, financial reporting, management, human resources, and technology. Various professionals - accountants, attorneys, economists, bankers, insurers, and appraisers, both within and outside the company-provide the tax expertise. Any major disruption to the team of tax professionals, such as the loss of tax consultants within the auditing firm, should make it more costly for firms to reduce their tax liabilities. 
To test this prediction, one would need data on taxes paid by corporations following the reduction in auditor-provided tax services. One would predict that taxes paid would increase the most in those firms that had the largest declines in auditor-provided tax services. There also could be a general time effect on tax collections to the extent that the tax industry is experiencing a period of conservatism following the accounting scandals, Sarbanes-Oxley and the recent crackdown on corporate tax shelters by the Internal Revenue Service (IRS).

Two, we expect to see the tax provision (the tax expense reported in the financial statements) as an increased source of conflict between the auditor and the client. Because financial statement auditors today are less likely to be reviewing the tax strategy developed by a colleague down the hall, they are more likely to question the tax strategy. All else equal, we expect that auditors will require their clients to record more tax cushion (a financial accounting reserve for tax positions that may be disallowed by the IRS) for a given level of aggressive tax positions than they did in the past. We expect that auditors will also maintain increasingly detailed audit workpapers related to the tax provision and that these workpapers will serve as a roadmap for the IRS to the client's most sensitive tax positions.

Three, we predict significant long-run changes to the accounting industry. The synergies that have long kept audit and tax professionals together in the same firms are now eroded. Given the shift away from obtaining tax services from one's audit firm, it is possible that there is no net positive synergy to having large tax practices together with the audit firms. This is far from certain, but we predict that over time portions of the Big Four tax practices will be sold or spunoff to entities that do not face the regulatory challenges the auditors face. In addition to standalone tax practices, potential buyers of parts of the Big Four tax practices include law firms, strategy consulting firms, human resource consulting firms, IT consulting firms, and even banks. 
Even without a sale or spin-off, portions of the Big Four tax practice may migrate to these same potential buyers as they enter the market or expand their existing tax services. Time will be necessary to test this prediction. We should note, however, that the short-run data do not support our long-run prediction. The total tax practices of the Big Four are currently expanding, not contracting, as they pick up business from each other's audit clients.

The remainder of the paper develops as follows: The next section provides background on the related literature and on the legislative and regulatory changes affecting auditor provided tax services. Section 3 provides some preliminary empirical evidence in terms of tax and audit fees. Section 4 speculates on the ultimate effects of the changes in tax service providers on the structure of the accounting industry. Section 5 discusses possible unintended consequences of Sarbanes-Oxley on aggregate corporate taxes. Concluding remarks follow.

\section{Background}

\subsection{Related literature}

Prior research has tended to ignore the role of auditor-provided tax services. The closest stream of research among tax papers examines the interplay between tax planning and financial reporting (see review in Shackelford and Shevlin, 2001; examples in Scholes et al., 2005). That literature, however, tends to focus either on firm-level coordination between tax planning and financial reporting incentives (e.g., LIFO versus FIFO) or on capital market responses to earnings in the presence of book-tax differences (e.g., Hanlon, 2005). When auditors are mentioned in the tax literature, they almost always are employees of the Internal Revenue Service, rather than accounting firms. In short, tax papers tend to ignore the role of the financial statement auditor. 
In the accounting literature, numerous papers study the market for auditors (e.g., Antle et al., 2002; Whisenant, 2003), auditing and the capital markets (e.g., Francis et al., 1999; Francis and Ke, 2004) and auditor independence (e.g., Antle, 1984; Ashbaugh et al., 2003; DeFond et al., 2002; Frankel et al., 2002; Kinney et al., 2004; Reynolds et al., 2004; Simunic, 1984). The independence literature is mixed on whether non-audit services compromise auditors. Using several tests for the presence of compromised auditors (e.g., the extent of earnings management) Frankel et al, 2002 conclude that having auditor provide non-audit services impairs auditor independence. Conversely, Ashbaugh et al. (2003) finds that the results in Frankel et al. (2002) are sensitive to research design choices. Similarly, Reynolds et al. (2004) finds no relation between non-audit services and discretionary accruals after controlling for certain firm characteristics. In a sample of financially-stressed manufacturing companies, Geiger and Rama (2003) find no association between non-audit fees and likelihood of receiving a going-concern audit opinion (loosely speaking, a going-concern audit opinion indicates that the firm may face financial distress). On the whole, the evidence is inconclusive whether non-audit services impair auditor independence.

Not surprisingly, researchers are beginning to analyze Sarbanes-Oxley from numerous angles (e.g., Asthana et al., 2004; Cohen et al., 2004; Griffen and Lont, 2005; Lai, 2003). However, we are aware of only one other study that examines the changing market for auditorprovided tax services, Omer et al. (2005). Among other things, that study finds a decline in auditor-provided tax services in 2002, the last year of its sample. 


\subsection{Legislative and regulatory changes affecting auditor-provided tax services}

To understand the legislative and regulatory changes to what auditors can do, it is important to understand the two categories of tax services that accounting firms typically provide. The first category of tax services are those that are not essential to the completion of the audit, including tax compliance, tax advice and tax consulting. Tax compliance involves filing tax returns and providing other information to the taxing authorities. Tax advice is responding to inquiries about the specific treatment of transactions or other taxable endeavors. Tax consulting is the design and implementation of tax strategies designed to manage tax liabilities. Of the three, consulting is the highest margin activity and includes profitable engagements such as restructuring organizations, shifting income across jurisdictions or time, or reclassifying the tax treatment of transactions. As detailed below, Sarbanes-Oxley discourages, and in some cases prohibits, accounting firms from providing these tax services to their audit clients.

The other services that tax professionals provide are those that are an essential part of the audit. Tax experts typically assist their audit brethren in the review of what is called the "tax provision,” i.e., the income tax expense in the corporation’s financial statements. The tax provision is not the actual taxes paid during that year. Rather, it estimates the total taxes over the life of the firm related to current year's activities. ${ }^{7}$ Auditing the provision estimates require extensive knowledge of both tax law and generally accepted accounting principles (GAAP). Because reviewing the provision is part of the audit, Sarbanes-Oxley does not prohibit auditors

\footnotetext{
${ }^{7}$ There are some exceptions to this general rule. For example, the tax provision can be affected by revisions in deferred tax assets and liabilities due to changes in tax rates, changes in the APB 23 election for permanently reinvested foreign earnings, changes in the valuation allowance, changes in the tax cushion and settlements with the IRS.
} 
from provision work. However, as discussed below, Sarbanes-Oxley indirectly affects the nature of the provision work.

Sarbanes-Oxley builds on three principles of auditor independence: (1) the auditor cannot audit his own work; (2) the auditor cannot function as part of management; (3) the auditor cannot serve in an advocacy role for the client. ${ }^{8}$ In other words, Sarbanes-Oxley is designed to ensure that the auditor remains independent, i.e., not conflicted in its audit of the financial reports. To that end, Sarbanes-Oxley specifically prohibits the firm that provides the audit from also providing: (1) bookkeeping or other services related to the accounting records or financial statements of the audit client; (2) financial information systems design and implementation; (3) appraisal or valuation services, fairness opinions, or contribution-in-kind reports; (4) actuarial services; (5) internal audit outsourcing services; (6) management functions or human resources; (7) broker or dealer, investment advisor, or investment banking services; (8) legal services and expert services unrelated to the audit; (9) any other service deemed by regulators to be impermissible.

Sarbanes-Oxley does not prohibit auditors from providing tax services to their audit clients and, in fact, specifically identifies tax services as services that the auditor can perform so long as pre-approval is obtained from the client's audit committee (Goodman, 2004). ${ }^{9}$

Nonetheless, Congress has given both the SEC and the newly-created PCAOB, discussed below, the authority to write rules regulating auditor independence. In 2003, following passage of the Sarbanes-Oxley Act, the SEC revised its auditor independence regulations. The revisions continue the SEC's longstanding position that accountants can provide audit clients with certain

\footnotetext{
${ }^{8}$ The SEC based its November 2000 amendments to the auditor independence rules on these same principles. They also guide the PCAOB, which Sarbanes-Oxley created to further oversee auditor-provided tax services. In addition, a Treasury Regulation known as Circular 230 regulates some aspects of tax practice, e.g., writing opinion letters.

${ }^{9}$ If Congress had been sufficiently concerned about tax impairing auditor independence, then it could have prohibited firms from offering both tax and audit services, much like the Glass-Steagall Act did for commercial and investment banking. See Kroszner, 1998; Kroszner and Rajan, 1994; and Kroszner and Rajan, 1997.
} 
tax services. The SEC considers tax services unique among non-audit services, noting that auditor-provided tax services predate the Congressional passage of the securities laws in the 1930s. The SEC, however, has ruled that independence is impaired by representing an audit client before a tax court, district court, or federal court of claims. ${ }^{10}$

The PCAOB was established by Sarbanes-Oxley as a new regulator of auditors. The PCAOB has proposed regulations that, among other things, delineate between acceptable and unacceptable tax services. ${ }^{11}$ It has ruled that auditor independence is compromised if the auditor participates in corporate tax planning under confidentiality or involving a "listed" transaction. ${ }^{12}$ In addition, the PCAOB forbids the accounting firm from participating in "aggressive” tax planning with its audit clients. Aggressive tax planning is defined as any plan or opinion where (a) the auditor provides any service related to the plan or opinion, (b) the client did not initiate the idea, (c) a significant purpose of the idea was to avoid taxes, and (d) the plan has a less than fifty-fifty chance of prevailing if challenged by the IRS. The PCAOB restrictions even extend to personal tax return preparation, barring the audit firm from preparing the personal tax returns for corporate officers with oversight authority over financial statements (Gary, 2004).

In addition to the SEC and PCAOB auditor regulations, Sarbanes-Oxley prohibits the audit firm from providing other tax services (e.g., ones that are not already prohibited) unless the audit committee approves the services in advance on a case-by-case basis. Audit committee approval can be a significant hurdle for at least four reasons. First, a primary responsibility of

\footnotetext{
${ }^{10}$ See Section B. 11 of http://www.sec.gov/rules/final/33-8183.htm\#footbody_103 for more details about the SEC's position about auditor-provided tax services.

${ }^{11}$ PCAOB Interim Professional Auditing Standards, issued April 18, 2003 and approved by the SEC on April 25, 2003.

${ }^{12}$ A "listed" transaction is one identified by the IRS as structured for the significant purpose of tax avoidance or evasion. Participants in listed transactions are required to disclose expected tax benefits and the identities and nature of involvement of all parties to the transaction. Among the 31 transactions currently listed are sale-in leaseout transactions, intercompany financing through partnerships, offsetting foreign currency option contracts, abusive foreign tax credit transactions, and S corporation ESOP abuses.
} 
the audit committee is to ensure that the auditor's independence is not compromised (potentially resulting in a failed audit). Thus, audit committees are predisposed toward limiting non-audit utilization of the audit firm. Second, audit committees historically have had little, if any, tax responsibility. It is unclear that corporate boards will add tax experts just to facilitate audit committee approval of auditor-provided tax services. Third, tax plans often demand rapid implementation for maximum effectiveness. To the extent audit committees cannot respond quickly, the audit firm may be precluded from some time-sensitive tax plans or dominated by non-auditor providers. Fourth, ignoring these tax approval responsibilities, Sarbanes-Oxley has already substantially increased the workloads of audit committees. Thus, it is unclear whether audit committees will place high priority on approving auditor-provided tax services. All in all, requiring audit committee pre-approval discourages firms from retaining their auditor to provide tax services.

\subsection{The Tax Provision as a New Source of Conflict}

Suppose a company adopts a tax plan designed to permanently reduce its taxes (as compared with inter-temporal shifting). The tax savings from the plan will only boost book income if the tax provision is reduced. Recall that the tax provision refers to the tax expense reported in the financial statements. The tax provision is not the same as the actual taxes currently paid because the tax provision estimates the total taxes over the life of the firm related to the current year's financial reporting revenues and expenses. Thus, temporary differences between tax and financial accounting income, such as accelerated tax depreciation, have no 
effect on the amount of tax expense reported for financial reporting purposes. ${ }^{13}$ If the only difference between tax and financial reporting income was due to accelerated depreciation for tax purposes, then financial reporting tax expense would exceed the actual tax liability in the early years of the asset's life. The pattern would reverse in the later years of the asset's life and over the entire life of the asset the cumulative tax expense for tax and financial reporting would be equal. On the other hand, permanent differences between tax and financial reporting, such as tax-exempt interest or non-deductible fines and penalties, do affect financial reporting tax expense.

Even when a tax plan creates a permanent difference and would seemingly reduce financial reporting tax expense, if the auditor does not believe that the tax plan will prevail under the scrutiny of the taxing authorities, he may not allow the booking of the tax benefit in the financial statements. In other words, if the auditor believes that the taxes foregone in the current year will be paid in future years after an IRS audit he may require the client to record a tax cushion (a reserve) to keep the tax provision from being understated. Because financial reporting earnings are important to a company's valuation, if the auditor does not permit a reduction in the provision, then the tax plan is less valuable and may not be marketable at all. Before the changes brought about by Sarbanes-Oxley and related events, purchasing tax services from one's auditor for the most part eliminated concerns that the auditor would oppose the firm's book treatment of the tax plan because the tax consultants would not promote a product that the auditors in their firm would not support. Since the same firm handled the tax and audit work, accounting firms were ideally positioned to sell corporate tax shelters. Auditors

\footnotetext{
${ }^{13}$ The composition of tax expense, however, will be affected. Tax expense for financial reporting is composed of current tax expense and deferred tax expense. Temporary differences between tax and financial reporting income give rise to deferred tax expense. See Scholes et al. (2005) for details.
} 
were not necessarily compromised under these arrangements, but the potential for conflicts of interest existed, and the perception of compromise was unavoidable.

The shift away from hiring one’s audit firm for tax services has substantially reduced these arrangements. Consequently, auditors today are less likely to be faced with attesting to the propriety of aggressive tax plans originated by their own firms. Instead, with the audit-tax link broken, the auditor's interests are contrary to those of the tax service provider. The tax planner needs a favorable tax and financial reporting outcome to promote his tax idea. The auditor, however, will be concerned that the actual taxes over the life of the firm may exceed those reported in the financial statements. The auditor has no financial interest in the success of the tax plan. Since the company must have an audit and its auditor cannot be conflicted by the success of the tax plan, the auditor today wields unprecedented clout in determining the tax strategies that the firm undertakes and how it accounts for them.

Consequently, the auditor now impedes, rather than assists, corporate tax avoidance. In fact, Hardesty (2004) intimates that with tax shelters, it is now easier to prevail in an IRS audit than to convince an auditor to accept favorable accounting. This outcome results from two influences, namely information and time. The auditor is more likely to know about the tax position and can command more cooperation and disclosure than the IRS can. In addition, pressure from the auditor to have more documentation supporting the tax provision and the reserves or "tax cushion" for future IRS audit adjustments is likely to greatly increase the ease with which the IRS can find aggressive tax positions. ${ }^{14}$ Furthermore, legal delays of years that

\footnotetext{
${ }^{14}$ The tax cushion is an increase in current tax expense beyond actual current tax payments to account for tax positions the firm has taken but believes it may lose upon IRS audit. In a related development beyond the scope of this paper, the Financial Accounting Standards Board (FASB) has recently proposed changes to the financial accounting treatment of "uncertain tax positions."
} 
increase the costs of IRS investigation are not possible with the auditor because the large SEC registrants are required to release their financial statements within 60 days of year-end.

In short, a (perhaps unintended) consequence of the pressure not to hire one's auditor for tax planning is that the auditor has switched from opposing to aiding the taxing authorities. The result of this role reversal should be increased taxes for financial reporting to the extent that auditors have become more conservative when reviewing the provisions of audit clients. In addition, the chilling effect on the ability to record the benefits of tax planning in the financial statements should reduce the amount and aggressiveness of tax planning and increase actual corporate tax payments.

\section{Initial Evidence from Audit Fees}

This section documents initial changes in auditor-provided tax services among the largest U.S. corporations. The operative word here is "initial." Because the accounting industry appears to be in transition from the effects of the accounting scandals, Sarbanes-Oxley, and related regulatory changes it is too soon to know for sure how extensive the long-run effects will be. However, these preliminary findings provide some sense of the magnitude of change. The remainder of this section details the fees paid by the largest U.S. companies to their auditors from 2001 to 2003.

\subsection{Audit and Tax Fee Data}

The primary tests compare the fees that a company pays to its auditors for audit work with the fees that it pays them for tax work. We collect the fee information from disclosures in the firms’ proxy statements. In January 2003, the SEC required companies to disclose a finer breakdown of the fees paid to their auditor: audit fees, audit-related fees, tax fees and all other 
fees. Before the rule change, tax fees were typically aggregated with other non-audit fees in the proxy statement disclosures. The finer partition disclosures were required for years ending after December 15, 2003, but corporations were required to report two years of information. Many companies chose to adopt the disclosure early and included information for 2001 and 2002 in their 2002 proxy statements. These early adopters are the companies that we principally analyze in this study.

The SEC defines "Audit Fees” as the total fees for professional accounting services for the audit or other services related to statutory or regulatory filings. “Audit-Related Fees” are payment for “...assurance and related services by the principal accountant that are reasonably related to the performance of the audit...” Throughout the study, we compare the tax fees both with the audit fees alone ("audit fees") and also with the audit fees combined with the auditrelated fees ("expanded audit fees”). Inferences are similar for both measures.

“Tax Fees” include fees for tax compliance, tax advice and tax planning, which is this paper's definition of tax services. The tax fees do not include review of the tax provision. Those fees are included in the audit fees. "All Other Fees” are for products and services provided by the auditor and not included in the other three categories. We largely ignore these fees in our analysis. See the Appendix for a reproduction of Allstate’s auditor fee information in its 2002 financial statements.

Because the fee classifications are self-reported (as is all other financial statement data), the empirical analysis below assumes that corporations can segregate the fees they pay to their auditors into these different categories and furthermore that they do so. To the extent the fee data are unreliable or manipulated in some manner to affect users of the financial statements, the results may be erroneous. We have no reason to think that the data are misleading but the 
possibility exists. Furthermore, if the precision in the categorical classification has changed over the 2001-2003 period, this also could introduce error into the study.

\subsection{Sample Selection}

We draw our sample from the Standard and Poor's 500 as of December 31, 2003. We exclude the 16 companies that do not detail their audit fees for 2001, 2002 and 2003 and the 235 companies that do not report the tax fees paid to their auditor for 2001, 2002 and 2003. One other company is dropped because data are missing from Compustat. Our sample consists of the remaining 248 companies that report both the audit and tax fees that they paid to their auditor in all three years. By definition, all of these firms adopted the SEC disclosures early.

If the companies that adopt early are systematically different from other firms, then our selection criteria may introduce bias. To assess how representative our sample is, we compare the 248 early adopters to the 247 S\&P 500 firms that did not adopt early and for which we have complete data.

We find that the early adopters are larger. In 2003, on average, early adopters’ assets were 159 percent greater; sales 164 percent higher; and market capitalization 174 percent larger than those of other S\&P 500 firms. Sales and market capitalization are significantly different at conventional levels. Book-to-market ratios, however, are insignificantly different (42 percent for early adopters in 2003 versus 44 percent for other firms). Both early adopters and other firms are evenly distributed across sectors.

More importantly, we find no difference in the tax-to-audit ratios between early adopters and other firms for 2002 and 2003. By definition, the early adopters are the only firms that disclosed fee information for 2001. However, all firms had to disclose audit and tax fees for 
2002 and 2003. When we compare the tax-to-audit ratios for 2002 and 2003, we find no significant difference. In 2002, the mean ratio for the early adopters is 0.71 versus 0.60 for the other firms. In 2003, the mean ratio for the early adopters is 0.48 versus 0.47 for the other firms. In summary, we find no evidence to suggest that the tax and audit fees of the early adopters are systematically different than those for other firms.

As expected, the Big Four accounting firms dominate the auditing market for the sample. For the three years combined in the study, both Ernst \& Young and PricewaterhouseCoopers audited 32 percent of the firms. Deloitte \& Touche audited 20 percent, and KPMG 11 percent. Arthur Andersen audited 10 percent of the sample in 2001. Arthur Andersen folded the following year with all of their S\&P 500 clients scattering among the remaining Big Four firms.

Eight companies changed auditors in 2001; 27 in 2002; and four in 2003. Twenty-five of the 2002 changes were Arthur Andersen clients who were forced to change after Arthur Andersen's demise. Thus, the sample only experienced 14 non-Andersen switches over the three years or 0.6 percent annually. To ensure that fee changes are not simply caused by changes in the auditors or by the forced Arthur Andersen's switches, we repeat our analysis excluding firms that experienced an auditor change. Inferences are unaltered.

\subsection{Empirical Analysis}

Table 1 presents descriptive statistics for the 248 S\&P 500 companies for which we have data from 2001, 2002 and 2003. The mean (median) firm in 2003 had a market capitalization of \$25 (\$10) billion, assets of \$48 (\$15) billion and sales of \$16 (\$8) billion. Both market value and sales show a dip in 2002, lingering effects of the 2001 recession. 
Of more central interest to this study is the audit and tax fees paid to the auditing firm. Table 2 shows that from 2001 to 2003 the mean (median) Audit Fees grew by 43 (30) percent, from $\$ 4.0$ (\$2.3) million to $\$ 5.7$ (\$3.0) million. Mean (median) Audit-Related Fees declined by 12 (17) percent, from $\$ 1.7$ (\$0.72) million to $\$ 1.5$ (\$0.60) million. One possible explanation for the decline in audit-related fees is that some firms are no longer purchasing their audit-related services from their auditor. Combining Audit and Audit-Related Fees to form Expanded Audit Fees, we find mean (median) expanded audit fees rose by 26 (26) percent, from $\$ 5.7$ (\$3.1) million to \$7.2 (\$3.9) million. Meanwhile, from 2001 to 2003, mean (median) Tax Fees for auditor-provided tax services tumbled by 20 (27) percent, from $\$ 3.2$ (\$1.5) million to $\$ 2.5$ (\$1.1) million. These findings are consistent with companies voluntarily reducing their demand for auditor-provided tax services. ${ }^{15}$

The combination of increased Audit Fees and decreased Tax Fees halves the mean (median) ratio of tax-to-audit fees, from 96 (68) percent in 2001 to 48 (36) percent in 2003. Similarly, when we compute the ratio using Expanded Audit Fees, the mean (median) ratio falls from 68 (49) percent to 39 (31) percent. Untabulated results show that the decrease in the ratio occurred for the firms that relied most heavily on their auditors for tax services. To demonstrate this difference, we split the sample on the median ratio in 2001, using Audit Fees in the denominator. The 124 firms above the median had an average ratio of 1.6. The 124 firms below the median had an average ratio of 0.3. Two years later the ratio for the above-median group had slipped to 0.7. The below-median group was unchanged at 0.3. Although regression toward the

\footnotetext{
${ }^{15}$ As an aside, All Other Fees fell precipitously with a mean (median) decline of 88 (95) percent, from \$3.7 (\$0.4) million to \$0.5 (\$0.0) million. This slump in All Other Fees is consistent with Sarbanes-Oxley restrictions on nonaudit services, companies no longer looking to auditors for services, other than audit and tax work, and auditors divesting their consulting practices.
} 
mean may explain part of this decline, it appears unlikely to account for all of it as there was no regression to the mean for the below-median firms.

The tax-to-audit ratios fell steadily from 2001 to 2003. Initial reports indicate that the decline continued in 2004. The Public Accounting Report (April 29, 2005) reported that the 430 Fortune 500 companies, for which data had been disclosed, paid 54 percent more for audit work in 2004 than they paid in $2003 .^{16}$ They added that the companies paid their auditors 11 percent less for tax work in 2004 than in $2003 .^{17}$

Assuming that these 430 Fortune 500 companies are comparable with the S\&P 500 for which we have 2003 data, we estimate that the 2004 tax-to-audit ratio was 0.26 or almost half the ratio in 2003. ${ }^{18}$ In other words, on average, the audit fees from audit clients were four times larger than the tax fees from them. In short, providing tax services to publicly-traded audit clients is a significantly diminished revenue source for the major accounting firms.

Initial audits of internal control documentation, as required by section 404 of SarbanesOxley were responsible for much of the increase in 2004 audit fees. Because it was the first year of section 404 documentation, 2004 may have been an aberration. However, a November 2004 Corporate Executive Board survey reported that only 12 percent of corporations expected their Sarbanes-Oxley costs to abate in $2005 .^{19}$ So, it is not clear that the tax-to-audit ratio will rebound in the near future. For now, the audit so dominates all other sources of fees from audit clients that actual or perceived audit compromise seems highly unlikely.

\footnotetext{
${ }^{16}$ Audit fees soared even higher for Fortune 501 to Fortune 1000 companies with an average increase of 75 percent. ${ }^{17}$ The article specifically identified tax work for audit clients as one fee area "getting pinched for auditors."

${ }^{18}$ Dropping Table 2's 2003 Tax Fees of \$2.53 million by another 11 percent produces estimated 2004 Tax Fees of $\$ 2.25$ million. Increasing Table 2's 2003 audit fees of $\$ 5.70$ million by 54 percent yields estimated 2004 Audit Fees of 8.78. $\$ 2.53$ divided by $\$ 8.78$ is 0.26 .

${ }^{19}$ The survey results can be found at http://www.cfo.executiveboard.com/Images/CTLR/PDF/Key\%20Insights\%20from\%20MHF.pdf on the fifth page of a report entitled, "SOX 404 Triggering Delayed Filings and CEO Turnover."
} 


\subsection{Analysis of Big 4 Audit and Tax Fees}

Further examination of detailed information from the Big Four accounting firms confirms the diminished role for auditor-provided tax services. In private conversations with top management at one of the Big Four accounting firms, we were told that approximately threequarters of their tax work was conducted for audit accounts for 2002. That figure declined 7 percent in 2003, another 7 percent in 2004 and will decline another 3 percent for 2005. Thus, they estimate that about 60 percent of their tax work is now with audit clients. They anticipate continuing erosion of their audit-client tax work until the percentage levels around 50 percent or slightly less.

These managers also asserted regional and industry differences in the retention of auditors for tax work. Companies in the Southwest and in the financial services industries are more likely to retain their auditors for tax services. They attribute the reticence of the financial service industry to the longstanding close relationship required between the auditors and the tax consultants in the regulated industries. In other words, they claim that the audit-tax coordination required for statutory filings in the regulated industries increase the costs of decoupling the auditor and the tax professional.

This assertion is consistent with evidence at another Big Four firm, Ernst \& Young. In their 2004 review, Ernst \& Young reports that audit clients now account for 63 percent of their business, down from 80 percent in 2000. This decline is remarkable for at least two reasons. First, the shift toward non-audit clients is largely limited to publicly-traded firms. Privately-held businesses are mostly unaffected by Sarbanes-Oxley and usually have no need to signal uncompromised audits. Second, fees from audits have soared in recent years. Thus, for the 
percentage of business from audit accounts to have declined by 17 percentage points (from 80 percent to 63 percent), at least one of two changes must have happened: (1) work for non-audit clients has soared (i.e., doing non-audit work for other firms' audit clients); (2) non-audit work for the firm's audit clients has plunged. More likely both conditions have occurred. That is, Ernst \& Young's non-audit professionals are winning work from other firms' audit clients, and Ernst and Young's audit clients are looking to other firms for their tax and consulting services. To quantify these shifts, we reviewed Ernst \& Young revenues by business lines. In 2000, we estimate that 60-87 percent of Ernst \& Young's tax work was done for audit clients. By 2004, we estimate no more than 21 percent of their tax work was for audit firms. In short, if our estimates are accurate, most of Ernst \& Young's tax work now comes from non-audit clients. Even if our estimates somewhat overstate the shift, the data still suggest a radical decline in tax work for audit clients in recent years. ${ }^{20}$

\footnotetext{
${ }^{20}$ For the year ended June 2000, their Assurance business line (which should comprise audit and audit-related services) generated $\$ 5.2$ billion or 57 percent of worldwide revenues. Assume that 90 percent of these audit services were provided to audit clients and recall that 80 percent of their 2000 work was conducted on audit clients. This fact pattern implies that another 29 [80 percent less (90 percent of 57 percent)] percentage points of audit revenues (or \$2.6 billion) must have come from their other three business lines (Tax, Transaction Advisory and Other).

Next, we attempt to estimate upper and lower bounds for auditor-provided tax work. Suppose no Transaction Advisory or Other services were provided to audit clients. Then, since Tax generated total fees of \$3.0 billion, the maximum percentage of tax work on audit accounts in 2000 was 87 percent ( $\$ 2.6 \div \$ 3.0)$. Conversely, suppose all Transaction Advisory services of $\$ 0.6$ billion and Other services of $\$ 0.2$ billion were conducted for audit clients, then the minimum percentage of tax work on audit accounts in 2000 was 60 percent [(\$2.6-\$0.6-\$0.2) $\div$ \$3.0] In summary, the data are consistent with 60-87 percent of Ernst \& Young's tax fees in 2000 coming from audit clients.

Let's compare those figures with 2004 data. For the year ended June 2004, the Assurance business line generated $\$ 9.0$ billion (62 percent of worldwide revenues), up 72 percent from 2000 . With 63 percent of Ernst \& Young's 2004 work conducted on audit clients, if we continue to assume that 90 percent of the audit services were provided to audit clients, then only 6 percentage points of audit revenues (or $\$ 0.9$ billion) came from their other three business lines (Tax, Transaction Advisory and Other). Again, suppose no Transaction Advisory or Other services were provided to audit clients. Then, since Tax generated total fees of $\$ 4.3$ billion, (up 27 percent from

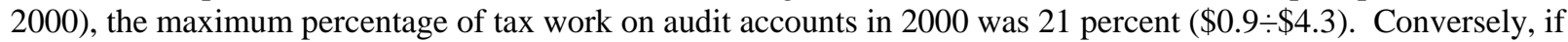
all of Ernst \& Young’s non-audit, non-tax services (Transaction Advisory services of \$1.1 billion and Other services of $\$ 0.2$ billion) were for audit clients, then none of their tax work related to audit accounts.
} 


\subsection{Has the Overall Amount of Corporate Tax Work Declined?}

An alternative explanation for the declining tax-to-audit ratios is that corporations are purchasing fewer tax services in total. In other words, perhaps auditor-provided tax work is not declining alone. Rather, accountants are providing less tax services to all clients, including their non-audit clients.

The Big Four data reject this proposition. In Ernst \& Young’s case, worldwide tax fees from both audit and non-audit clients rose 27 percent from 2000 to 2004. Although this increase pales in comparison to the 72 percent leap in worldwide audit fees, it is consistent with Ernst \& Young continuing to generate large fees from tax work, albeit perhaps not for audit clients. Ernst \& Young, however, reports worldwide fees. If tax work outside the U.S. soared, then these calculations may mask an underlying shrinkage in U.S. tax revenues. To test this possibility, we turn to financial information from another Big Four firm, Deloitte \& Touche.

Deloitte \& Touche reported U.S. tax fees of \$1.2 billion for the year ended May 2002. Two years later, total U.S. tax fees were $\$ 1.8$ billion, a 43 percent jump. During the same period U.S. audit revenues rose 50 percent from $\$ 1.8$ billion to $\$ 2.8$ billion. Thus, the Deloitte \& Touche data suggest that their U.S. tax work is not receding at all. In fact, it appears to be growing at a rapid pace, although probably much stronger for non-audit clients, than for audit accounts.

We also find evidence of a sharp increase in non-U.S. tax work. From 2002 to 2004, Deloitte \& Touche’s worldwide tax revenues leapt 58 percent (from $\$ 2.4$ billion to $\$ 3.8$ billion) while worldwide audit fees rose 51 percent (from $\$ 4.9$ billion to $\$ 7.4$ billion). This increase means that non-U.S. tax fees rose 74 percent in two years from $\$ 1.2$ billion to $\$ 2.0$ billion. Meanwhile, non-U.S. audit revenues were up 52 percent from $\$ 3.1$ billion to $\$ 4.6$ billion. 
Other data, however, suggest that Deloitte \& Touche’s increase in tax fees may be exceptional. Data from a trade publication, the Public Accounting Report, reveal that aggregate U.S. tax fees for the Big Four increased from approximately $\$ 5.5$ billion in 2002 to approximately $\$ 6.0$ billion in 2003, a one-year increase of approximately 9\%. Excluding Deloitte \& Touche, however, aggregate U.S. tax fees increased by only $2.6 \%$. Nevertheless, at least for 2002-2003, we detect no evidence of a drop in aggregate U.S. tax fees.

Finally, it appears that attorneys have increased market share as a result of restrictions on auditor-provided tax services. PricewaterhouseCoopers vice-chairman John O'Connor reportedly estimates that his firm has lost about 3 percent of its tax practice to law firms. ${ }^{21}$ Because law firms do not routinely disclose the percentage of their revenue from areas of legal practice (e.g., general corporate, litigation, tax), we are unable to further quantify the extent of this possible shift in market share to law firms.

\section{Industry Restructuring}

As would be expected, restrictions on auditor-provided tax services are affecting both auditors and tax professionals. In its review of 2004, Ernst \& Young notes “...the shifting market [for publicly-traded audit clients] is having an unprecedented impact on our people, with our assurance and risk services resources strained to capacity, while activity has softened in other service areas, most notably tax planning” (Global Review 2004, p.14).

As the tax work has moved among firms, some tax experts have switched accounting firms. Others have left accounting firms for other tax practices, such as law or consulting firms, that are unencumbered by these new restrictions. Also, new tax services providers are emerging in wake of the Sarbanes-Oxley restrictions. For example, Alvarez and Marsal, a global

${ }^{21}$ http://www.cfoasia.com/archives/200402-05.htm 
professional service firm, expanded into tax consulting in 2004. In a January 2005 press release announcing the hiring of eight prominent tax professionals, Bob Lowe, head of their tax practice, said:

"The need for management teams and boards of directors to maintain independence from their auditors has led to increased scrutiny of tax services provided by an audit firm. This need for independent tax advisors has begun to spur an exodus of senior tax professionals from Big Four accounting firms....we continue to attract the industry's leading tax professionals who are excited by the opportunity to work with a multidisciplinary firm that does not and will not perform audits. Since we will not offer audit services, our Managing Directors will not be faced with the types of independence conflicts that hinder a Big Four firm tax partner's ability to serve clients.”

Alvarez and Marsal has met resistance in its attempt to build a major tax practice of former Big Four tax professionals. After Alvarez and Marsal hired 13 tax consultants from Ernst \& Young, the accounting firm sued them for raiding its personnel, interfering with its business and misappropriating confidential information. In a Wall Street Journal article (March 18, 2005, C1), the tax consultants claimed that they were fleeing the constraints of Sarbanes-Oxley.

Leaving an accounting firm can be costly for partners. They can lose substantial capital and retirement benefits and face lengthy covenants-not-to-compete, which can thwart their ability to pursue clients of their former firm or recruit former colleagues. One tax partner privately told us that he switched Big Four firms so that he could continue to provide tax services to the clients that he had worked with for the last 20 years. However, his covenant-not-tocompete precludes his soliciting former clients or rebuilding his staff with former colleagues for two years. Nevertheless, he concluded that his skills were so client-specific that he would be better off to wait two years and pursue his former clients, rather than begin now to rebuild his tax practice with non-audit clients. 
Moreover, firm-specific skills and relationships are costly to replicate. Entire careers are devoted to applying highly technical skills to a single firm. The tax director of one of the country's largest financial service firms privately told us that it would take years to develop the firm-specific tax and business expertise that currently resides among the tax consultants at the accounting firm that has conducted its audit for decades.

An alternative to employee reshuffling is that the Big Four accounting firms could spinoff or sell their tax practices, thus eliminating the Sarbanes-Oxley constraints. Each firm acknowledges that it has considered dividing. However, to date, no firm has taken this final step. We understand that to facilitate division, one of the Big Four has moved its tax practice to a separate corporation, although retaining the same management.

In the past, significant opportunities existed to sell tax services more effectively and at lower cost to one's audit clients. This created an economic attraction that caused tax and audit specialists to operate synergistically in the large accounting firms. Today, it appears quite possible that the former attraction is now repulsion. As the data on the decline of tax fees coming from audit clients indicate, tax specialists in many cases appear effectively precluded from the very work that used to be nearly guaranteed. Based on the dramatic changes already evident in the data, we are skeptical that a net synergy remains to having tax and audit specialists in the same firm as their respective client bases diverge from one another. To be sure, auditing firms will always need some tax specialists to assist with the tax provision, e.g., auditing the tax numbers that appear in the financial statements. But provision work would surely require only a small fraction of the tax specialists that currently work for the large accounting firms. In addition, the career path for a tax professional who only does provision work is likely less profitable than one involving tax consulting and planning. 
Ironically, Sarbanes-Oxley is providing both the pressure to split audit and tax practices and the force to hold them together, at least for now. Tax partners, as discussed above, have an incentive to press for an organizational structure unencumbered by Sarbanes-Oxley restrictions. ${ }^{22}$ However, Sarbanes-Oxley and particularly its section 404 internal control documentation are currently generating unprecedented audit fees. Since audit and tax partners tend to share profits somewhat equally, Big Four audit partners today are said to be heavily subsidizing their tax colleagues. In other words, one explanation for the lack of audit-tax division within the Big Four is that the Sarbanes-Oxley boost to audit fees exceeds its disruption to tax practices. Thus, an audit-tax split may be inevitable, but it may be temporarily delayed until the audit profits from Sarbanes-Oxley dissipate. In the long run, however, large cross-partner subsidies could cause instability, as it reportedly did in the eventual break up of Arthur Andersen and Andersen Consulting (now Accenture) in the 1990s.

Another factor that increases the incentive to sell or split-off part of the Big Four tax practices is that the explicit and implicit restrictions on auditor-provided tax services substantially shrinks the competition for both services. The restriction effect would be immaterial if the pool of prospective accounting firms was large. Instead, the "Big Four" accounting firms—Deloitte \& Touche, Ernst \& Young, KPMG, and PricewaterhouseCooopers— audit almost every large company in the country. Their audit market share exceeds 99 percent of the market capitalization of S\&P 500, and they provide similar portions of the external tax accounting advice for these companies. Moreover, for most corporations, the pool of prospective auditors and tax accountants is even smaller than four firms because the firms specialize along industry lines. Consequently, once the auditor is removed as a tax service provider, many

\footnotetext{
${ }^{22}$ The potentially catastrophic costs associated with failed audits (as seen in Arthur Andersen's collapse) is another reason for tax practitioners to separate from auditing firms.
} 
companies realistically only have only one or two other accounting firms to access for tax expertise.

At first it might seem natural that the large law firms acquire tax practices from the accounting firms or gradually acquire the underlying work and add personnel over time. Indeed, one could imagine a great deal of synergy to having tax accountants and tax lawyers working in the same firm. In fact, that is precisely the direction the Big Four were going in the 1990s as they hired a significant number of tax attorneys, sometimes at considerable premiums over what they were making in their former law firms. ${ }^{23}$ Anecdotally, this migration is reversing with tax attorneys returning to law firms.

Although synergies exist between the work that tax accountants and tax lawyers do, law firms are unlikely to acquire large portions of the Big Four tax practice for at least two reasons. The first reason is size. The law market is highly fragmented. Even the largest law firms are tiny compared with the Big Four accounting firms. Consequently, no law firm is large enough to acquire the entire tax practice of even the smallest Big Four firm. As of 2003, the largest law firm in the U.S. had revenues of approximately \$1.3 billion, and only three other U.S. law firms had revenues in excess of $\$ 1$ billion. ${ }^{24}$ Moreover, the tax practice within the law firms would be only a small fraction of the total revenues; the majority likely being general corporate work and litigation work. By comparison, the U.S. tax practice of the Big Four in 2003 ranged from nearly $\$ 1.2$ billion for KPMG to almost $\$ 1.9$ billion for Ernst \& Young. ${ }^{25}$ In short, the U.S. tax practices of the Big Four are indeed deserving of the "big” moniker, exceeding in size the entire tax and non-tax practices of all but the very largest U.S. law firms.

\footnotetext{
${ }^{23}$ This practice led to several legal skirmishes about whether the tax attorneys working at the Big Four were improperly engaging in the practice of law, and the limitations, if any, on a tax attorney after he moved from a law firm to a Big Four accounting firm.

${ }^{24}$ These data come from the “Am Law 100” list complied by The American Lawyer_(July 2004). The four largest law firms per the Am Law 100 are Skadden Arps, Baker \& MacKenzie, Jones Day, and Latham \& Watkins.

${ }^{25}$ These data are from the Public Accounting Report “Top 100 for 2004,” September 14, 2004.
} 
The second reason not to expect law firms to acquire major portions of the Big Four tax practice is regulatory; in this case a restriction on law firms. We understand that, in most jurisdictions, law firms are not permitted to share profits with non-lawyers. In other words, law firms are regulated to be “pure” law firms, making it nearly impossible for law firms to expand into other lines of business. (These rules also effectively shield law firms from being taken over by anything other than another law firm.)

Furthermore, it is unlikely that large amounts of existing Big Four tax work could shift to law firms in the absence of their ability to hire tax accountants because accounting tax and legal tax skills are not fully interchangeable. A good deal of tax work, including most compliance work and some consulting work, is not well suited for lawyers because it is quantitative rather than verbal. As a gross simplification, tax lawyers tend to have a comparative advantage in verbal aspects of taxation (e.g., interpretation of the case law surrounding the assignment of income doctrine) while tax accountants tend to have a comparative advantage in quantitative aspects of taxation (e.g., analyzing the tax costs and benefits of various repatriation strategies).

However, other entities that do not face such constraints could have synergies with tax specialists. For example, strategic consulting firms, such as McKinsey, could have synergies with tax to the extent their existing work gives them enough knowledge of the client's business to facilitate cross-selling of tax services. Human Resources consulting firms, such as Mercer, already employ some tax specialists and could see that work grow as they face less competition from their clients’ audit firms. IT consulting firms such as Accenture and IBM, could have synergies with process oriented aspects of tax, such as compliance. Investment and commercial banks could conceivably find it worthwhile to offer a broad range of tax services, as the selling of tax services can sometimes lead to high margin work implementing the transactions needed to 
carry out the tax planning. In short, even with no wholesale split of the Big Four tax practices, portions of the tax work could move to non-audit professional firms over time as those firms see an opportunity to enter the market or acquire pieces of the Big Four tax practices.

\section{Unintended Consequences: More Corporate Tax Collections}

We expect to see a chilling effect on tax avoidance activities. These strategies have been the subject of much research and speculation, and observers have pointed to the growing gap between book and tax income over the 1990s as evidence of increased corporate tax avoidance activities (see Plesko, 2004; Hanlon and Shevlin, 2004; Mills, Newberry and Trautman, 2002; among others)). One unintended consequence of having a different provider of tax services than one's auditor could be to reduce the level of corporate tax aggressiveness and increase corporate tax collections.

We expect that auditors will be far less willing to accept tax planning strategies developed by a rival firm than by their tax colleagues down the hall. Anecdotal reports support the expectation that auditors are requiring much more detail in the workpapers supporting the "tax cushion." The tax cushion is the reserve that companies maintain to account for the positions they have taken on their tax returns that they may lose once audited by the IRS. Under certain conditions, IRS auditors can request/demand to see a company's tax accrual workpapers, including the tax cushion, which can serve as roadmap to the parts of the tax return the company would rather the IRS not scrutinize. Now the roadmap, because of changes in the audit market, is increasingly detailed. It is possible that the financial statement auditor has become the single most effective deterrent against aggressive tax avoidance strategies. To test this prediction, one would need data on taxes paid, financial reporting tax expense, and the shift in obtaining tax services from one's auditor to other service providers. 
Having said that, it is not obvious that collections will increase. Another possibility is that tax planners will become more aggressive now that they are no longer impeded by their audit partners. In the past, tax advisers from the audit firm suffered if the audit failed. No longer bearing the costs of an audit failure, tax advisers may press for increasingly aggressive positions. If so, the restrictions placed on auditor-provided tax services could actually serve to increase tax avoidance.

Another possible effect could come from as auditors become privy to the latest tax technology at competitor firms and can share this information with the tax advisors in their firms. In equilibrium, this could cause tax consultants to reserve their best tax ideas - those that save taxes at low risk - for clients that continue to use them for both audit and tax.

It will take a good deal of research before we can conclusively resolve the revenue effects of decoupling audit and tax services. We expect that the net result of the restrictions on auditorprovided tax services will be an increase in tax collections. Auditors, as the final arbitrators of the financial statements, should prevail in most cases against highly aggressive tax advisers from other firms because auditors can demand complete disclosure in a timely manner from the tax adviser. Our expectation, however, relies critically on the assumption that auditors choose to maintain an aggressive posture toward manipulation of the financial statements and demand full disclosure of the firm's tax position. If auditors shrink from the heightened tension between them and tax advisors, then tax planning could indeed become more aggressive.

\section{Conclusions}

Following Sarbanes-Oxley, accountants have dramatically reduced the tax work that they conduct for audit clients, while increasing the amount of tax work that they do for non-audit 
clients. We estimate that from 2001 to 2004 the typical company went from paying its auditor the same for audit and tax services to paying the auditor only one-fourth as much for tax services as for audit services. This decline is reshaping the landscape for corporate tax consulting.

The future is still hazy, but a few predictions seem plausible. One, because auditors in the past had competitive advantages over other tax service providers, corporate taxes and the costs of tax avoidance will increase. Two, although Sarbanes-Oxley and related changes have reduced or eliminated the synergies that once existed between providing both audit and tax services to the same client, high audit fees are providing a short-term incentive for tax partners to stay in auditing firms. In the long-run, if this tend continues we anticipate instability and the eventual sale or spin-off of significant portions of the Big Four tax practices. Even if no firm spins-off or sells its tax line of business, some non-trivial amount of tax work will migrate to non-audit firms, including law firms, consulting firms, and investment and commercial banks. Three, a consequence of the decoupling of tax and audit services is that when the auditor reviews the tax provision, he is no longer judging tax strategies developed by his own firm. Consequently, we predict that auditors will be more likely to require the client to record tax cushion for aggressive tax positions to protect against the financial reporting tax expense from being understated. Furthermore, the financial auditors are increasingly requiring detailed workpapers backing up the tax provision. This documentation will serve as a roadmap for the IRS in subsequent corporate tax return audits. These forecasts reflect the massive impact that the accounting scandals, Sarbanes-Oxley, and related regulatory changes have already had on the world of corporate tax planning; effects that will continue to reverberate for years to come. 


\section{Appendix}

\section{Allstate's Disclosure of the Fees Paid to Deloitte \& Touche in its 2002 Financial Statements}

The following fees have been, or will be, billed by Deloitte \& Touche LLP, the member firms of Deloitte Touche Tohmatsu, and their respective affiliates, for professional services rendered to Allstate for the fiscal years ending December 31, 2002 and December 31, 2001.

\begin{tabular}{|c|c|c|c|}
\hline & \multicolumn{2}{|c|}{2002} & 2001 \\
\hline Audit Fees(1) & $\$$ & $6,063,752 \$$ & $5,275,465$ \\
\hline Audit Related Fees(2) & $\$$ & $963,328 \$$ & 213,365 \\
\hline Tax Fees(3) & $\$$ & $81,551 \$$ & 99,374 \\
\hline All Other Fees(4) & $\$$ & $61,807 \$$ & 624,735 \\
\hline Total Fees & $\$$ & $7,170,338 \$$ & $6,212,939$ \\
\hline
\end{tabular}

(1)Fees for audits of annual financial statements, reviews of quarterly financial statements, statutory audits, audit services, comfort letters, consents and review of documents filed with the Commission.

(2) Audit Related Fees relate to professional services such as accounting consultations relating to new accounting standards, due diligence assistance and audits of non-consolidated entities (i.e. employee benefit plans, various trusts, Allstate Foundation, etc.) and are set forth below. The fees associated with the 2001 audits of these entities (totaling \$416,150) were not included in last year's Proxy Statement.

\begin{tabular}{|c|c|c|c|}
\hline \multirow[b]{2}{*}{ Adoption of New Accounting Standards } & \multicolumn{2}{|c|}{2002} & 001 \\
\hline & $\$$ & $16,610 \$$ & 169,612 \\
\hline Due Diligence & $\$$ & $479,861 \$$ & 23,903 \\
\hline Audits of Non-consolidated Entities & $\$$ & $432,010 \$$ & - \\
\hline Other & $\$$ & $34,747 \$$ & 19,850 \\
\hline Audit Related Fees & $\$$ & $963,228 \$$ & 213,365 \\
\hline
\end{tabular}

(3) Includes fees for tax compliance, consultation and planning

(4) All Other Fees primarily include professional fees for consulting services related to financial and non-financial information systems, as well as fees for other consulting services:

Strategic Planning

Non-Financial Information Systems

Business Consulting

Lease Consulting

Financial Information Systems Design \&

\begin{tabular}{lrr}
\multicolumn{2}{c}{2002} & \multicolumn{2}{c}{2001} \\
$\$$ & $40,727 \$$ & - \\
$\$$ & $-\$$ & 445,353 \\
$\$$ & $-\$$ & 67,580 \\
$\$$ & $7,710 \$$ & 62,804 \\
$\$$ & $-\$$ & 9,160
\end{tabular}




\section{Implementation \\ Other}

All Other Fees

\begin{tabular}{lll}
$\$$ & $13,370 \$$ & 39,838 \\
\hline$\$$ & $61,807 \$$ & 624,735
\end{tabular}

NOTE: Audit, Audit Related and All (Non-Audit Related) Fees for 2001 were reclassified to present them in accordance with prospective expanded disclosure requirements. Consents for product filings and registration fees $(\$ 483,200)$ previously classified as Audit Related are now considered Audit Fees. Tax services $(\$ 99,374)$ were included as All Other Fees in the 2001 Proxy Statement and are now in a separate Tax Fees category. 


\section{References}

Antle, R. “Auditor Independence.” Journal of Accounting Research 22:1 (1984): 1-19.

Antle, R., E. Gordon, G. Narayanamoorthy, and L. Zhou. "The joint determination of audit fees, non-audit fees and abnormal accruals.” (2002) Working paper, Yale University.

Asthana, S., S. Balsam, and S. Kim. "The effect of Enron, Andersen, and Sarbanes-Oxley on the market for audit services.” Working paper, Temple University and Rutgers University (June 2004).

Ashbaugh, H., R. Lafond, and B. Mayhew. "Do nonaudit services compromise auditor independence? Further evidence.” The Accounting Review 78:3 (2003): 611-639.

Bankman, Joseph. “The Tax Shelter Battle.” The Crisis in Tax Administration, edited by Henry J. Aaron and Joel Slemrod. Washington, D.C.: The Brookings Institution (2004).

Borrus, A. and N. Byrnes. “Auditors: the leash gets shorter.” Business Week (December 20, 2004).

Cohen, D., A. Day, and T. Lys. “The effect of the Sarbanes-Oxley Act on earnings management: what has changed?” (2004) Working paper, Kellogg School of Management, Northwestern University.

Deloitte Touche Tohmatsu. Worldwide member firms 2004 review (2004).

Deloitte \& Touche. "Facts \& Figures.” www.deloitte.com.

DeFond, M., K. Raghunandan, and K. Subramanyam. “Do nonaudit service fees impair auditor independence? Evidence from going concern audit opinions. Journal of Accounting Research 40 (2002):1247-1274.

Ernst \& Young. Global 2004 review.

Francis, J., E. Maydew and C. Sparks. "The Role of Big 6 Auditors in the Credible Reporting of Accruals.” Auditing: A Journal of Practice and Theory. (1999): 17-34.

Francis, J., and B. Ke. "Disclosure of Fees Paid to Auditors and the Market Valuation of Earnings Surprises.” (2004) Working paper, University of Missouri and Pennsylvania State University.

Frankel, R., M. Johnson, and K. Nelson. “The relation between auditors’ fees for nonaudit services and earnings management.” The Accounting Review 77 (2002):71-105.

Gary, K. “PCAOB approves proposed auditor independence rules.” Tax Notes (December 20, 2004): 1603-1604. 
Geiger, M. and D. Rama. "Audit fees, nonaudit fees, and auditor reporting on stressed companies.” Auditing: A Journal of Practice \& Theory 22:3 (2003):53-69.

Griffen, P. and D. Lont. "The effects of auditor dismissals and resignations on audit fees: evidence based on SEC disclosures under Sarbanes-Oxley.” (2005) Working paper, University of California at Davis.

Goodman, G. “The taxpayer's and tax adviser’s guide to Sarbanes-Oxley.” Tax Notes (August 4, 2004): 691-712.

Graham, John R., Cam Harvey and Shiva Rajgopal, 2005, The Economic Implications of Corporate Financial Reporting, Journal of Accounting and Economics forthcoming.

Hanlon, M. "The Persistence and Pricing of Earnings, Accruals, and Cash Flows When Firms Have Large Book-Tax Differences.” The Accounting Review (2005).

Hanlon, M. and T. Shevlin. "Book-Tax Conformity for Corporate Income: An Introduction to the Issues.” University of Michigan working paper, 2004.

Hardesty, D. "Sarbanes-Oxley compliance in the corporate tax department." State Tax Notes (November 29, 2004): 589-596.

Kinney, W., Z. Palmrose and S. Scholz. “Auditor independence, non-audit services, and restatements: was the U.S. government right?” Journal of Accounting Research 42 (2004): 561-588.

Kroszner, R. "Rethinking bank regulation: a review of the historical evidence.” Journal of Applied Corporate Finance ( Summer 1998): 48-58.

Kroszner, R. and R. Rajan. "Organization structure and credibility: evidence from commercial bank securities activities before the Glass-Steagall Act.” Journal of Monetary Economics 39 (August 1997): 475-516.

Kroszner, R. and R. Rajan. "Is the Glass-Steagall Act justified? A study of the U.S. experience with universal banking before 1933.” American Economic Review 84(4) (1994): 810832.

Lai, K. “The Sarbanes-Oxley Act and auditor independence: preliminary evidence from audit opinion and discretionary accruals.” Working paper, City University of Hong Kong (2003).

KPMG. International 2004 annual report.

McLean, B. and P. Elkind. The Smartest Guys in the Room: The Amazing Rise and Scandalous Fall of Enron. New York, NY: Penquin Group (2003). 
Mills, L., K. Newberry and W. Trautman. "Trends in Book-Tax Income and Balance Sheet Differences.” Tax Notes 96 No. 8 (August 19) (2002): 1109-1124.

Omer, T., J. Bedard, and D. Falsetta. “Auditor Provided Tax Services: The Effects of a Changing Regulatory Environment.” (2005) Working paper.

Plesko, G. "Corporate Tax Avoidance and the Properties of Corporate Earnings.” National Tax Journal (September 57) (2004): 729-737.

PricewaterhouseCoopers. 2004 Global annual review.

Reynolds, J., D. Deis, and J. Francis. "Professional Service Fees and Auditor Objectivity.” Auditing: A Journal of Practice \& Theory 23:1 (2004):29-52.

Sarbanes-Oxley Act of 2002. P.L. No. 207-204. Washington, DC: Government Printing Office.

Securities and Exchange Commission (SEC). Final Rule: Revision of the Commission's Auditor Independence Requirements. (2000) Washington, DC: Government Printing Office.

Securities and Exchange Commission (SEC). Final Rule: Strengthening the Commission's Requirements Regarding Auditor Independence. (2003) Washington, DC: Government Printing Office.

Scholes, M., M. Wolfson, M. Erickson, E. Maydew, and T. Shevlin. Taxes and Business Strategy. $3^{\text {rd }}$ Edition. Upper Saddle River, NJ: Pearson / Prentice Hall (2005).

Shackelford, D. and T. Shevlin. "Empirical tax research in accounting.” Journal of Accounting and Economics 31 (2001):321-387.

Simunic, D. “Auditing, Consulting, and Auditor Independence.” Journal of Accounting Research 22:2 (1984): 679-702.

Whisenant, S., S. Sankaraguruswamy, and K. Raghunandan. "Evidence on the joint determination of audit and non-audit fess.” Journal of Accounting Research (2003): 721744. 
TABLE 1

\section{Descriptive Statistics}

Sample consists of S\&P 500 firms with available tax and audit fee data for 2001 to 2003

$$
\mathrm{N}=248
$$

\begin{tabular}{|c|c|c|c|c|c|c|c|c|c|}
\hline Variable & Year & & 75th Pctl & \multicolumn{2}{|c|}{$\begin{array}{c}\text { Mean of Yearly } \\
\text { Differences }\end{array}$} & $\begin{array}{l}\text { Median of Yearly } \\
\text { Differences }\end{array}$ \\
\hline & 2001 & 0.37 & 0.53 & 0.28 & 0.35 & 0.39 & & & \\
\hline \multirow[t]{2}{*}{ Effective Tax Rate } & 2002 & 0.27 & 0.44 & 0.24 & 0.32 & 0.37 & \multicolumn{2}{|c|}{$-0.11 * *$} & $-0.01 * * \star$ \\
\hline & 2003 & 0.43 & 1.82 & 0.25 & 0.33 & 0.37 & \multicolumn{2}{|l|}{0.16} & $0.00 * \star \star$ \\
\hline \multirow{3}{*}{ Return on Assets } & 2001 & 0.04 & 0.10 & 0.01 & 0.03 & 0.07 & & & \\
\hline & 2002 & 0.02 & 0.12 & 0.00 & 0.03 & 0.07 & -0.01 & ** & $0.00 * \star \star$ \\
\hline & 2003 & 0.05 & 0.07 & 0.02 & 0.04 & 0.08 & 0.03 & $\star \star \star$ & 0.01 *** \\
\hline \multirow{3}{*}{ Market Value of Equity } & 2001 & $25,339.14$ & $49,114.19$ & $4,833.19$ & $8,122.73$ & $23,505.92$ & & & \\
\hline & 2002 & $20,302.69$ & $36,099.98$ & $3,774.66$ & $7,259.04$ & $17,602.39$ & $-5,013.80$ & $\star \star \star$ & $-790.62 * \star \star$ \\
\hline & 2003 & $25,043.94$ & $44,319.41$ & $4,999.97$ & $9,729.73$ & $23,824.91$ & $4,741.25$ & $\star \star \star$ & $2,080.21$ *** \\
\hline \multirow{3}{*}{ Total Assets } & 2001 & $40,968.09$ & $105,274.56$ & $4,044.10$ & $12,473.50$ & $28,617.61$ & & & \\
\hline & 2002 & $43,086.41$ & $112,548.50$ & $4,178.43$ & $13,833.50$ & $29,577.50$ & $2,322.99$ & ** & 342.65 *** \\
\hline & 2003 & $47,615.94$ & $128,285.59$ & 4,984.91 & $14,565.25$ & $30,375.77$ & $3,899.24$ & $\star \star \star$ & 737.71 *** \\
\hline \multirow{3}{*}{ Sales } & 2001 & $15,579.06$ & $25,518.33$ & $2,683.53$ & $7,125.32$ & $16,937.50$ & & & \\
\hline & 2002 & $14,785.10$ & $24,783.36$ & $2,742.14$ & $6,964.18$ & $15,756.00$ & -793.96 & ** & $-40.55 * \star * *$ \\
\hline & 2003 & $16,125.55$ & $26,957.91$ & $3,023.66$ & $7,771.50$ & $17,235.25$ & $1,340.45$ & $\star \star \star$ & 417.09 *** \\
\hline
\end{tabular}

$\star \star \star \star * \star, *$ indicates significance at the 1\%,5\%, or $10 \%$ level, respectively. Market Value of Equity is price multiplied by shares outstanding at the fiscal year end. Total assets and sales are compustat items \#6 and \#12, respectively. Effective tax rate is income tax expense divided by pretax income. Return on Equity is Net Income divided by Shareholders Equity at the fiscal year end. Means and medians of yearly differences are means and medians of firm specific differences. Means are tested using a t-test, medians are tested using the sign-rank test. 
TABLE 2

Tax Fees and Audit Fees and Paid to Auditors

Sample consists of S\&P 500 firms with available tax and audit fee data for 2001 to 2003 $\mathrm{N}=248$

\begin{tabular}{|c|c|c|c|c|c|c|c|c|}
\hline Variable & Year & Mean & Std Dev & 25th Pctl & Median & 75th Pctl & $\begin{array}{l}\text { Mean of Yearly } \\
\text { Differences }\end{array}$ & $\begin{array}{c}\text { Median of Yearly } \\
\text { Differences }\end{array}$ \\
\hline \multirow{3}{*}{ Tax Fees } & 2001 & 3.16 & 4.47 & 0.55 & 1.50 & 3.48 & & \\
\hline & 2002 & 2.83 & 4.17 & 0.49 & 1.20 & 2.98 & $-0.33 * \star \star$ & $-0.07 * * *$ \\
\hline & 2003 & 2.53 & 4.03 & 0.43 & 1.11 & 2.35 & $-0.30 * *$ & $-0.10 * * *$ \\
\hline \multirow{3}{*}{ Audit Fees } & 2001 & 3.99 & 5.15 & 1.16 & 2.31 & 4.37 & & \\
\hline & 2002 & 5.05 & 6.23 & 1.31 & 2.70 & 5.72 & $1.06 * * \star$ & $0.38 * * *$ \\
\hline & 2003 & 5.70 & 7.31 & 1.59 & 3.01 & 6.12 & $0.65 * \star \star$ & $0.34 * * *$ \\
\hline \multirow{3}{*}{ Audit-Related Fees } & 2001 & 1.70 & 2.65 & 0.27 & 0.72 & 1.99 & & \\
\hline & 2002 & 1.44 & 2.71 & 0.21 & 0.50 & 1.53 & -0.26 ** & $-0.04 * * *$ \\
\hline & 2003 & 1.50 & 2.81 & 0.27 & 0.60 & 1.35 & 0.06 & $0.01 * * *$ \\
\hline \multirow{3}{*}{$\begin{array}{l}\text { Expanded Audit Fees (Audit Fees + } \\
\text { Audit-Related Fees) }\end{array}$} & 2001 & 5.70 & 7.17 & 1.63 & 3.10 & 6.40 & & \\
\hline & 2002 & 6.49 & 8.33 & 1.77 & 3.42 & 7.46 & $0.80 * * *$ & $0.24 * * *$ \\
\hline & 2003 & 7.20 & 9.54 & 1.92 & 3.92 & 8.50 & $0.70 * \star *$ & $0.39 * \star \star$ \\
\hline \multirow{3}{*}{ All Other Fees Paid to Auditor } & 2001 & 3.72 & 9.01 & 0.04 & 0.43 & 2.50 & & \\
\hline & 2002 & 2.06 & 8.48 & 0.00 & 0.11 & 0.89 & $-1.66 * \star \star$ & $-0.10 * \star \star$ \\
\hline & 2003 & 0.45 & 2.09 & 0.00 & 0.02 & 0.16 & $-1.61 * \star \star$ & $-0.03 * * *$ \\
\hline \multirow{3}{*}{ Total Fees Paid to Auditor } & 2001 & 12.57 & 17.28 & 3.05 & 6.21 & 14.15 & & \\
\hline & 2002 & 11.38 & 16.99 & 2.73 & 5.32 & 11.32 & $-1.19 * *$ & $-0.10 * * *$ \\
\hline & 2003 & 10.17 & 13.64 & 2.71 & 5.43 & 10.75 & $-1.20 * \star \star$ & $0.03 * * *$ \\
\hline \multirow{3}{*}{ Tax Fee to Audit Fee Ratio } & 2001 & 0.96 & 1.07 & 0.33 & 0.68 & 1.26 & & \\
\hline & 2002 & 0.71 & 1.15 & 0.23 & 0.48 & 0.85 & $-0.25 * \star \star$ & $-0.12 * \star * \star$ \\
\hline & 2003 & 0.48 & 0.47 & 0.16 & 0.36 & 0.62 & $-0.24 * \star * \star$ & $-0.08 * * *$ \\
\hline \multirow{3}{*}{$\begin{array}{l}\text { Tax Fee to Expanded Audit Fee } \\
\text { Ratio }\end{array}$} & 2001 & 0.68 & 0.76 & 0.24 & 0.49 & 0.86 & & \\
\hline & 2002 & 0.53 & 0.66 & 0.17 & 0.38 & 0.68 & $-0.15 * * \star$ & $-0.06 * * *$ \\
\hline & 2003 & 0.39 & 0.39 & 0.13 & 0.31 & 0.53 & $-0.14 * * *$ & $-0.05 * * *$ \\
\hline
\end{tabular}

$* * * * * *$ indicates significance at the $1 \%, 5 \%$, or $10 \%$ level, respectively. Audit fees, audit related fees, tax fees, other fees and total fees are as reported in the footnotes to the financial statements. The tax fee to audit fee ratio is tax fees divided by audit fees. Means and medians of yearly differences are means and medians of firm specific differences. Means are tested using a t-test, medians are tested using the sign-rank test. 